\title{
Draft
}

\section{Educational leadership: an Islamic perspective}

Concepts, theories and practices in education are predominantly ethnocentric ${ }^{1}$, embedded in Western philosophy and values (Dimmock 2000). The same applies to a large extent, to the concepts and practices linked to educational leadership in the multi-ethnic British society. This approach tends to ignore the rich diversity of the societal fabric where more than a quarter of the population is of different ethnic origins (National Statistics 2001), with diverse socio-cultural and knowledge heritages.

The growing multi-cultural nature of educational institutions (Shah 2004) underpins the need to acknowledge, and to respond to this diversity. Different cultures reflect different values and patterns of behaviour (Marsh 1994). Accordingly, cultural circumstances alter the views that people take about a given issue (Greenfield 1993: 461) and influence approaches and practices. This paper is an effort to draw attention to the knowledge gap in theory and application regarding diverse perspectives of educational leadership - an issue which is foreseen as gaining higher significance with the fast changing societal structures in Britain.

This paper discusses an Islamic perspective of educational leadership. The current focus is influenced by the fact that there are 1.8 million Muslims in Britain (The Guardian 2002), and according to the National Statistics (2001), they emerge as the largest religious group after Christianity. Secondly, unlike some other faith groups, Muslims tend to highlight their religious identity (Brah 1996; Jacobson 1998; Modood 1990; Modood et al 1997; Nielsen 1987). And finally, any association between the ethnicity/identity and educational performance/achievement of the Muslim students in the British education system should not foreclose the possibilities of exploring the impact of how leadership is conceptualized by them. 
According to the national statistics (2001), 52\% Muslims in Britain fall within the age category of under 24, and 50\% are British born citizens not 'sojourners', as Haddad (2002) argues, and many are in HE (Modood 1997: 73; 82) with implications for educational leaders regarding expectations and experiences of these young people. $33.8 \%$ of the Muslims are aged 0-15 years and fall within the compulsory education age. How they conceive and perceive educational leadership, and how they receive it, is bound to interact with their learning experience and performance. Furthermore, in the backdrop of the current increasing demand for faith schools from the Muslims in Britain, a multidirectional knowledge sharing can be contributive to societal cohesion and stability as well as to improved practice and performance on educational sites.

This paper introduces leadership as a concept formulated in context. It briefly presents philosophical and theoretical underpinnings of these conceptualizations from an Islamic perspective, and discusses the broader aims of education in Islam and their contribution towards the development of 'self' (nafas), to provide a background to locate educational leadership. The high status of knowledge in Islam and the interplay between knowledge and leadership, which underpin notions of educational leaders in Muslim societies, are explored to provide a philosophical anchoring to these conceptualisations. How these discourses interact to formulate concepts of educational leadership in Muslim societies is discussed next. The implications of these constructions in the societies where Muslims are in minority are debated in the final section with a focus on the British context and the notions of educational leadership in the Western leadership literature.

\section{Educational Leadership in Context}

The concept of educational leadership varies across societies and cultures. Different interpretations of leadership reflect the ways of looking at it and the philosophical and theoretical assumption behind them:

... classifications, theories and descriptions depend not only upon the way the world is but also upon what it is we want to show or display. It is not reasonable to suppose 
that there could be one classification or descriptive scheme, which could serve for all purposes. (Hughes 1990:158)

Variations in interpretation arise also because in different societies 'leadership derives power and influence from different formal or informal sources of position, person, knowledge, and wisdom' (Mullins 1995:229; also Handy 1995; Sergiovanni 1984). Even similar concepts and procedures carry different meanings and understandings, for example:

For the Russians the consensus has traditionally been something handed down in fully approved form from a centralised authority, whereas in Canada consensus is usually something established by a group of professionals working locally. (Begley 2003:46)

Relevant literature highlights that the culture and ethos of leadership also "differ in fundamental ways across nations" (Fullan 1992:viii). How a particular society perceives and constructs educational leadership, therefore, needs to be understood and debated in context. When leadership is wrenched from the context and theorised, the complexity and ambiguity of the concept and subsequent difficulties in interpretation/s increase. Pugh and Hickson discuss education as a 'deeply cultural institution' (Pugh and Hickson 2003:11) where theory and practice are shaped by the values, beliefs, ideologies, behaviour and conventions in that social system. Child makes a similar argument, using the Weberian framework of formal rationality and substantive rationality to explain the impact of ideational systems (cultural, religious and political) on social institutions, placing education on the top (2003: 42).

Hofstede's landmark study, in spite of the fact that it focuses on business management, highlights the interplay between the culture and the practices, involving the managers (leaders!) and the managed (led!). He argues that ideas about leadership reflect the dominant culture (2001: 388), and cites examples to draw attention to the effect of societal conceptualisations on leadership practices. He compares countries like Norway and Sweden 
'where management assumed that initiative was to be taken by the subordinates', while in the USA this tends to be seen as an infringement of the 'management prerogatives'; and from a high power/distance culture like Greece the subordinate's complain was 'He is the boss. Why doesn't he tell me?' when the expatriate US boss asked his opinion on how much time a job should take (2001: 389). Walker \& Dimmock (2002) discussing the impact of societal and organizational cultures on leadership theory and practice in education, argue that the notion of educational leadership is formulated in the backdrop of values, patterns of behaviour and ideologies of a community. For example, the patriarchal notion of leadership in China draws its power and responsibilities from the social ideology drawn from Confucius, and functions within that value system (Tung, 2003). In Chinese society, social harmony is highly valued, and it determines the leadership concepts and practices expectations and responses - as reflected in the decision-making processes of a group of Hong Kong principals (Walker 2002).

'Leaders' and the 'led' participate in related activities informed by their ideological and cultural knowledge - transmitted from generation to generation and learned through living and sharing with a group or community as its member - explained by Bourdieu (1977) as 'habitus'. An absence of the 'tacit knowledge' (Polanyi 1967) gained through 'habitus' poses an awareness gap for those leading educational institutions in multicultural societies, and this requires deliberate efforts to devise measures for becoming better informed.

As different cultures, societies and communities construe leadership in different ways, the need to explore these constructions becomes highly significant in multi-ethnic contexts. In Islam, association between religion, knowledge and teaching creates a discourse of educational leadership, which elevates teaching/learning to a sacred duty of the highest order. The notion of teacher-leader in religious texts (Shah 1999a), and associated discourses (Talbani 1996; Foucault 1977; 1980) has historically influenced and continues to influence these formulations and conceptualisations. 
From an Islamic perspective, 'leading' has strong connotations of leading towards knowledge and 'righteousness', through 'words' and 'acts', entailing a knowledge status for the teacher/leader, as well as perceiving her/him as a role model in a holistic sense, and this is debated in the next section. This conceptualization of teacher-leader, to a certain extent, has been shared by different religions (Islam, Christianity, Hinduism), cultures (Chinese, Japanese), and ideologies (Bourdieu 1977; Freire 1972; 1973). There is no denying that under the impact of globalization, market pressures, institutional reorganizations, and internationalisation of technology, the blurred boundaries between teacher and leader, even in the more traditional societies, are changing into sharper distinctions between teacher-leader/manager-leader in some aspects. However, these socio-economic processes are also introducing multiple similarities in leadership practices and theorising across diverse contexts. This may not eliminate specific ideological features in some cases, but it could provide a forum for engagement and for enhancing understanding.

\section{An Islamic Perspective: Islam, Knowledge and Self}

Religious texts and teachings of Islam propound a particular philosophy of education and educational leaders, which provides a basis for similarities of concepts and practices within the overarching umbrella of Muslim $U m m a h^{2}$, and also underpins the perceptions and responses of Muslims in predominantly non-Muslim contexts. In spite of variations across the range of Muslim societies, sacred religious texts remain the sources of legitimation, contributing to a philosophical likeness. Any variations within and across these societies are formulated at various intersections influenced by multiple factors. However, developments perceived as deviations from Islamic teachings often entail intense political and intellectual engagement to avoid 'legitimation crisis' (Habermas 1976; Giddens 1990) that could cause complications at implementation stage, as has been the case in Pakistan over the recent years, in the efforts towards curriculum development (Nayyar and Salim 2002) and improving the system of examinations (Ali 2005; Hussain 2005). 
The notion of educational leadership in Islam derives from Islamic philosophy of education, and contextual variations of conceptualization and practice across Muslim societies involve interpretations informed by an understanding of religious texts, which reinforces the interplay between faith and concepts. Muslim scholars often argue that the social, educational and related notions and concepts in Muslim societies 'cannot be truly appreciated without some accurate understanding of the Islamic faith and civilisation' (Tabawi 1972:19). The basis of the Islamic philosophy of education is located in faith as reflected in the Quranic caveat that God is the ultimate knower (2.32):

... and above every one possessed of knowledge is the All-knowing One.

(The Quran 12.76)

The claim is that all knowledge rests with God, and human beings are the best of creation because they partake of this Godly quality:

God has bestowed on [human beings], and [human beings] alone among all the created things, ability to recognise, understand, and emulate the attributes of God, and realise them in practice in this life. (Hussain and Ashraf 1979:10)

The ontological debates and epistemic questions regarding the philosophy of knowledge in Islam and the nature of human knowledge are beyond the scope of this paper $^{3}$. The focus here is on the concept of educational leadership from an Islamic perspective, and the debates contributing to the development of this concept in Muslim societies. Nevertheless, some understanding of the nature of knowledge and the importance of the acquisition of knowledge from a Muslim perspective may be useful to understand why leadership, especially educational leadership is construed in particular ways by Muslims.

Islam, with its claims to universality and comprehensibility, seeks to encompass every aspect of human endeavour. The aim of Islamic education is to develop humans through knowledge to enable them to follow the path of righteousness, and to become useful members of the Ummah and the society. This underpins the faith dimension of 'education 
for all" ${ }^{4}$ in Islam where learning becomes a religious obligation, "compulsory on every Muslim male and female" (Karim 1938:351), spanning the whole life ${ }^{5}$ (Al-Attas 1979; Ashraf 1995; Maududi 1980; Nasr 1985; Tibawi 1972). The role of Islamic education is perceived as giving meaning to life and enriching it, instilling discipline and preserving human values, and strengthening and advancing human societies. These perceptions contribute to enhanced expectations of Muslim learners and communities from educational institutions and leaders.

The Islamic theory of education derives from the Quranic concepts (Abdullah 1982:43). The nature of knowledge (revealed and acquired) and its contribution towards individual's holistic development are some such elements that shape the approach, and determine the role of knowledge and the knowledge-givers. The stress on seeking and acquiring knowledge is one of the basic tenets of Islam, (Al-Bukhari, Vol. 1), emphasizing that only those who have knowledge 'tread the path of righteousness (taqwa)' (the Quran 35:28), and it is linked to elevated status:

O mankind, We have created you from male and female; and We have divided you into tribes and sub-tribes so that you could know each other. Verily the most honoured (akramakum) of you in the sight of God is the most righteous (atqakum) of you. (The Quran 49:13)

Righteousness is attained through knowledge and by application of that knowledge to every aspect of life. The aim of education in Islam is to prepare human beings for leading a life of 'righteousness' in a social context which underpins relevant conceptualizations on educational sites.

In Islam, education is for the holistic development, and religion is not a mere set of moral principals, but a complete system encompassing and integrating the political, social, and economic, as well as personal, moral, and spiritual aspects of life (Dabashi 1993:439; also Maududi 1980; Nasr 1985). Learning and knowledge are not a matter of individual choice or priority, determined by personal needs or market forces. It is a duty imposed by God and 
defined as the path to 'righteousness' (Al-Attas 1979; Ashraf 1995; Tibawi 1972). Seeking knowledge is $j i h a d^{6}$, an effort in the way of $\operatorname{God}^{7}$ (Al-Bukhari, Vol. 1), aiming at the development of individual as a whole being so that s/he acts for the sake of God:

If any do deeds of righteousness, be they male or female, and have faith, they will enter paradise. (The Quran 4:124)

Proceeding from this thesis, 'self' is the site where knowledge articulates, and educational leaders are perceived as playing a significant role in this process. The Quranic view of self is dynamic with an infinite capacity for development:

'Verily We will raise you to higher and higher levels' (84:19)

And self is not a passive recipient of 'higher levels'. In fact, it is an active participant in actualising its potentialities, possessing an agency in creating and developing its subjectivity:

The self (nafs) owns only that which it earns and it changes through what it assimilates, good or bad. (The Quran 74:38)

The role of educational leadership, by virtue of being involved in knowledge building, and because of the status of knowledge in Islam (the Quran 2:70), is a major contributing factor to this 'process of becoming' (Choudury, 1993:6). Furthermore, seeking knowledge has a collective dimension - to share that knowledge with others. Teaching/learning pertains to the realm of haqook-al-abaad (obligations of human beings to one another), and teaching is the duty of the prophets ${ }^{8}$ who are perceived as Muallams (knowledgegivers). The emphasis on the importance of teaching/learning underpins the high status of teachers and educational leaders. As the aim of education embraces the development of the Ummah and the society, this extends the role of educational leaders and teachers beyond the institutions. The emphasis on the social and collective in Islam is evident in 
the pronouncement that 'God will forgive the sins of faith but not those committed against other human beings' (Al-Bukhari).

\section{$\underline{\text { Islam, Education and Leadership }}$}

The Islamic philosophy of education draws from the belief that God, the ultimate knower, 'taught to man the knowledge of things' (the Quran 96:1-5). The discourse of God as teacher raises teaching/knowledge-giving to the level of the highest-status activity and establishes the link between knowledge, knowledge sharing and leadership. Adam, the first human being in Islamic theology was made vicegerent on earth because God had 'taught Adam the nature of things' (the Quran: 2:31). To this Adam the angels were asked to perform 'sijda' (the Quran 2:34). The ensuing argument between God and the Archangel as to the cause of Adam's superiority (the Quran 2:30-33) underpins the high status of knowledge in Islam, and its association with leadership. The question is forcefully and clearly raised in the Quran:

Are those who possess knowledge and those who do not on equal footing? ${ }^{10}$ (The Quran: 39:9)

The relevant points that emerge here are that in Islamic philosophy of knowledge, ultimate knowledge lies with God, and human knowledge is limited and fragmentary; secondly, knowledge and giving knowledge are Godly attributes; and thirdly, knowledge and sharing knowledge (teaching/learning!) are the sources and justification of status and leadership. This perspective contributes to the blurring of boundaries between teacher and leader, and underpins theoretical constructions of educational leadership in Muslim societies. The Quran repeatedly emphasises that none can grasp the meaning of revelations except men of understanding and those firmly grounded in knowledge (the Quran: 3:7-8; $6: 105 ; 22: 55 ; 24: 6)$, thus suggesting that only those who possess knowledge and understanding are capable of guiding and leading people, the tasks obligatory for the prophets. The promise made in a later verse that "God will raise in ranks those of you who believe as well as those who are given knowledge" (the Quran 58:11) is another example of 
the relationship between knowledge and status. The prophets, otherwise ordinary human beings, have elevated status among mankind because of their knowledge ${ }^{11}$ :

And certainly We gave knowledge to Dawood and Sulaiman, and they both said: Praise be to Allah, Who has made us to excel many of His believing servants. (The Quran 27:15)

And then:

... their prophet said to them: Surely Allah has raised Talut to be a king over you. They said: How can he hold kingship over us while we have a greater right to kingship than he, and he has not been granted an abundance of wealth? He said: Surely Allah has chosen him in preference to you, and He has increased him abundantly in knowledge. (The Quran 2:247)

The prophets are often referred in the Quran as teachers. For example, the prophet Mohammed, who was a religious and political leader, also taught men and women (Al-Hibri 1982; Mernissi, 1991), and was called muallam (teacher). From this convergence of the religious, social, political, and educational roles, evolves a concept of educational leadership in Islam, which has retained some of its distinctive ideological features over time.

In addition to that, teacher/leader (Muallam) has the authority and status of a parent - the highest authority in the Islamic social system (the Quran 6:151; 17:23; 29:8-9; 31:14; 46:15). Its transference to the teaching role is indicative of the utmost respect accorded to teacher by the religion, and has implications for managing and leading Muslim students in multi-faith contexts like Britain. This concept of parent-like authority vested in teacher/leader is balanced by responsibilities and by an emphasis on values and accountability; nevertheless, it provides another source for teacher's authority and leadership role, blurring the boundaries further. From this brief discussion, emerges a three dimensional model of educational leadership with explicit overlaps: 
- Teaching with knowledge and understanding - educator

- Guiding with wisdom and values - prophet/leader

- Caring with responsibility and commitment - parent

This merging of the discourses problematises conceptualisations across the range of Muslim societies and over times due to organisational changes, but the centrality of the teaching role and its association with leading dominates formulations of leadership concepts, with knowledge and knowledge-giving as significant dimensions. Teaching, leading and caring become intertwined activities, with a wider remit. Islam agrees with the broad educational aims of creating 'good individuals' and 'good citizens' but it attaches great importance to faith, piety and moral values as fundamental aims of education (Al-Attas 1979:V). This widens the dimensions of the teacher's task, creating 'a close relationship between the teacher and the taught, spiritual as well as professional' (Al-Attas 1979:111), combining the teacher and a wider leadership role into one. Men of knowledge and learning guide the learners nearer to God and are attributed the highest status as the 'heirs of prophets' (Al-Bukhari), which is one reason of a deeply embedded concept of respect for the teacher ${ }^{12}$ in Muslim societies, and contributes to the acceptance of their leadership role.

The fusion of multiple roles within the discourse of educational leadership underpinned the notion of high respect for the teacher/leader, particularly in early Islam, and it was strengthened by the assumption that guiding towards knowledge was an act of giving which could not be repaid. This explains why in the first few centuries of its advent there was no concept of a paid teacher in the Muslim world ${ }^{13}$. The Muslim scholars taught in mosques or homes to all those who came seeking knowledge (Al-Attas 1979:97). The ancient seats of learning in Islam grew up around certain personalities who attracted people alike for their learning and their piety (Hussain and Ashraf 1979:104). It was a process of 'giving' knowledge and developing the self-developing the person of the learner as a whole by providing guidance in all areas of personality. From this close articulation between religion and education emerged an Islamic notion of educational leadership, where knowledge and 
the conduct of the teacher/leader both contributed in guiding the learners' progress towards intellectual, moral and material development.

However, the situation continued undergoing changes and modifications as Islam spread into further areas, and interacted with different religions, cultures, and socio-economic backgrounds. Al-Azhar was the first formal seat of learning established in Egypt in the fourth century, and was followed by Al-Nizamiyyah in Baghdad, where state-paid teachers were appointed (Tibawi 1972:30). These developments in education added new dimensions to the role of 'the leading scholar', involving management of more formal structure, but without displacing the teacher/leader discourse. The Muslim rulers respected and admired eminent scholars, and at times sought their approval to win the public support. Bernstein's in his interesting discussion of knowledge and control states:

The way a society selects, classifies, distributes, transmits, and evaluates educational knowledge reflects both the distribution of power and the principles of social control. (1987:47)

Local and global economic, social, and political changes are leading different societies towards redefinitions of leadership role in different educational contexts, where the leader "either provides solutions to the problems of people, or brings the hope that solutions are possible" (Iqbal 1981:182). However, from an Islamic perspective, the institutional leadership continues to involve more than organizational management, including the responsibilities for the holistic development of the learners and the wider community. The teacher is perceived as a leader, within and beyond the classroom context, expected to fulfill the leadership role as a guide to knowledge and conduct, and to be a role model. This blurring of boundaries between the teacher and leader points to the extent of the expectations of Muslim students from the educational leaders and teachers, and can partly explain the respect and status commanded by the people in educational leadership positions, as well as the frustrations when the expectations remain unsatisfied. 


\section{$\underline{\text { Educational Leadership and Muslim Communities }}$}

Globalisation (Giddens 1993; Reeves 1995), communication explosion (Braun and Warner 2003), internationalisation of technology, and economic universalism (Child 2003) are drawing the world closer and smoothing out many differences in practices in diverse fields of human activity, across societies and countries. However, there is an increasing awareness of diversity and of the issues of identity embedded in cultures and social systems (Anwar 1998; Brah et al 1999; Hall 1993; Tajfel 1978; Vincent 2003), which is reflected in concepts and practices in education.

In the case of Islam, issues of identity and impact of ideational systems on education and related concepts have deeper significance. In spite of the Modernism of the post-SecondWorld-War world, with its emphasis on 'meta narratives' of democracy and equality nudging religion to the background, the tensions between the liberal and the religious thoughts in education have continued (Ahmed 1992), escalating with the revival of religions in the post-modern world (Ahmed 1992; Ahmed and Donnan 1994; Bauman 1996; 1997). The educational sites have, consequently, become locations for the interplay of competing notions and discourses (Foucault 1980), adding to the challenges of managing and leading multiethnic educational institutions.

As mentioned above, the Muslims tend to highlight their religious identity, irrespective of the level of commitment to religious practices. They are identified both by themselves and others as Muslims. Discussing why the British Muslims' 'attachment to their religion is not progressively weakened or diluted as a result of the fact that they are living in nonMuslim society' (Jacobson, 1998:126), Jessica Jacobson explains three levels of religious oriented actions that make them distinctive - at the level of normal practice (prayers etc), routine behaviour (dietary issues), and social conduct (morality code etc) (1998:128). She treats religion (separately from ethnicity) as a basis of social identity in the case of Muslims, and explains it as 'commitment to a universalistic religion with a global reach' (1998:11). 
Secondly, the history and the tradition of the religious institutions of learning (usually called madaras), which are, and have been led by religious scholars (Ulema) in the Muslim societies, have contributed to sustaining the relevant conceptualisations. These educational leaders have helped maintain the notion of educational leaders as spiritual, moral and academic mentors. Even in the present day Muslim societies, when there are ongoing heated debates concerning the knowledge status of the Ulema ${ }^{14}$ and their teaching missions, the number and sizes of these institutions have been growing not only in the Muslim countries like Afghanistan, Indonesia, Lebanon, Pakistan and many others, but even in many Western countries where Muslim are in minorities. The Ulema, due to the tradition of respect accorded to religious scholars in Muslim societies, have enjoyed an easier access to masses in Muslim communities as compared to formal state-managed educational institutions; and in the absence of critical engagement with religious knowledge ${ }^{15}$ among the masses, they have commanded respect and obedience through control over interpretation of religious texts and discourses (Foucalt 1988; Shah 1998; Talbani 1996). The teachers' leadership role and power diluted within the formal hierarchical power structures are thus re-appropriated within a religious discourse.

Thirdly, the ultimate source of reference in Islam is the Quran ${ }^{16}$. There can be variations in the interpretations of the Quranic teachings and commands (Al-Hibri 1982; Shah 1998) but no refutations. The vast range of Muslim societies may formulate diverse interpretations but the validation and authenticity of these interpretations is dependent on alignment with the authentic religious texts, mainly the Quran and the Hadith (the sayings of the prophet Mohammed). The concept of the teacher as leader derives directly from the Quran and the Hadith, and in spite of the debates around definitions of knowledge, teacher, leadership, and the realities of a material world, it retains associations with status and respect in the Muslim societies. One explanation can be that the education policies and systems of different Muslim states, such as Iran, Pakistan, Saudi Arabia and others, explicitly acknowledge their religious orientation and ethos, thus adding to the power of the discourse. For example, the first stated aim of Pakistan's National Education Policy (1998-2010) is: 
Within the context of Islamic perception, education is an instrument for developing the attitudes of individuals in accordance with the values of righteousness to help build a sound Islamic society.

All teachers/educational leaders are required to possess certain religious knowledge to fulfil their roles as guides to knowledge and conduct, in keeping with the Quranic teachings. The specific guidelines in this policy document detail how to train all staff (teachers and leaders), who are also held responsible for 'dissemination of information on fundamental principles of Islam as laid down in the Holy Quran, and as applicable to the development of an egalitarian Muslim society' (National education Policy 1998-2010: 3.4.7.). The recruitment format for all staff emphasises basic knowledge of Islam, ability to read the Quran, religious practices and moral values as essentials. The political compulsion to acknowledge their Islamic identity for legitimacy purposes can be an issue faced by the Islamic countries, but this contributes to sustaining certain similarities across communities.

Admittedly, there are conceptual variations, not only in different Muslim societies and countries, but also between different types of educational institutions (Siddique 1998). For example, the educational leaders in the religious schools (madaras) in countries like Pakistan and Indonesia ${ }^{17}$, and the government institutions in both the countries are expressions of different conceptualisations, reflected in leadership styles and perceptions. However, the essential position remains unchallenged theoretically, that an educational leader must be a constant seeker and giver of knowledge, who acquires the right and responsibility to lead through knowledge, in the tradition of the prophets. In addition to that, an educational leader, from an Islamic perspective, is one who practices what s/he teaches, thus ascertaining links between theory and practice.

The next section weaves together the discussion with a focus on the British context. It will seek to highlight the conceptual similarities and shared-ness in some notional fields between an Islamic leadership concept and some widely acclaimed Western notions of educational leadership. 


\section{Implication in the societies where Muslims are in minority}

The primary aim of education in Islam is 'to facilitate developing those values whose roots are in the attributes of God and which God has planted within human beings as potentialities" (Ashraf 1995). The educational leaders should ideally bring out these 'potentialities' and develop them to the maximum possibilities, with a focus on 'holistic development'. This philosophy of education, to some extent, is reflected in the liberal concept of education promulgated by thinkers like Freire (1972). This extends the role of the educational leader beyond the educational to include the intellectual, social, moral, spiritual, and even personal, with the responsibility of leading the people to the "right path', or in Freire's words, to' transform the world' (1972:27). This also implies that the leader should possess the highest values, or as constructed in the Islamic philosophy, '.. the one whom Allah has given wisdom and he acts according to it and teaches it to others' (Al-Bukhari Vol. 1).

In spite of a philosophical uniqueness located in faith, Islamic notions of educational leadership share significant aspects of different leadership concepts, propounded in the Western literature. Similarities can be perceived across certain dimensions of Islamic notions of educational leadership and the leadership concepts such as reflective, transformational, ethical/moral, collaborative, dialogical and 'servant leadership'. Goddard briefly describes fourteen leadership styles identified from the literature (2003:14), and in his discussion of servant leadership - where leadership has 'no personal gain' but is only for a 'just and right' cause - he offers examples of Mohammed, Buddha and Christ as 'the great religious teachers of the past' (2003:16). This concept of 'servant leadership' (Greenleaf 1996) for 'no personal gain', is reflected in the concept of unpaid,

committed Muallam in early Islam (Shah 1999). But this is just one dimension ${ }^{18}$ of a complex concept. It is a multidimensional notion, and as such bears similarities and differences. An enhanced understanding can add to developing the concept to the satisfaction of wider stakeholders in multi-cultural contexts. The remaining discussion will focus on certain shared attributes, arguing that myriad facets of Islamic philosophy 
of educational leadership bear certain similarities with mainstream theorizing. The need is to recognize and value the overlaps, and avail these for enhanced understanding.

In a presentation to the 2002 International Thinking Skills Conference, Robert Sternberg emphasises that educational leaders need wisdom. This growing emphasis on 'wisdom in leadership' (Ribbins 2003:171), 'reflection' (Schon 1983) and 'values' (Hodgkinson 1991) reflects diverse aspects of Islamic notions of educational leadership expounded fourteen centuries ago. This highlights how two different sources and frameworks of thinking have come to similar understandings. Discussing 'What is good leadership? What is good leader?' Peter Ribbins (2003:172) highlights the role of 'wisdom ${ }^{19}$, and an understanding of values for the good leaders. Hodgkinson is very explicit in articulating the point that 'other things being equal, [institutions] will wish to appoint the wise men and women to its administrative offices' (1996:8). These caveats reverberate the Quranic endorsement of people of knowledge and wisdom ${ }^{20}$ as being the prophets, leaders and Muallams - who are guided by these qualities in reflection and practice.

The concept of reflective leadership (Schon 1983) has been gaining widespread acclaim over the last few decades. It is perceived as leading to self-understanding and understanding others, which can help resolve conflicts, tensions, and problems of division in organisations and societies. In Islam, meditation and reflection are highly emphasized as the attributes of prophets (Muallams!):

And He has made subservient to you whatsoever is in the heavens and whatsoever is in the earth, all, from Himself; most surely there are signs in this for a people who reflect. (the Quran 45:13)

The earlier discussion highlighted the fluidity of the roles of prophets and Muallams. Mohammed, the first educational leader in Islam (Ali 1964; Mernissi 1991a; Watt 1961), spent thirteen years in meditation before he was ordained as one who 'teaches ... [people] the Book and the wisdom and teaches ... that which you did not know' (the Quran 2:151), and this underlines the interaction between teaching, leading and reflection. 
Withdrawing from 'public' and going into seclusion to reflect remained a feature of Mohammed's demeanor throughout his life (Mernissi 1991a). This practice echoes in Greenfield and Ribbins, suggesting to the educational leaders to withdraw from practice to reflect, arguing for:

"a kind of philosophic withdrawal to look at the larger issues in fresh perspectives. Perhaps they will return and administer as they were doing it before, but with an added insight". (Greenfield and Ribbins 1993: 257)

The high emphasis on reflection in Islamic theory and practice reverberates in Schon's (1983) theory of reflective practice and in Greenfield and Ribbins' argument that 'We need leaders in education who can think about the larger issues' (1993:258-9). Reflection is increasingly being perceived as creating a space to think and analyse, a stance equally valued for learning (Bloom 1964; Kolb 1984) and leading (Schon 1987). Many studies recommend 'those stepping into the school leader's role to spend time reflecting on personal values, ethical stances and other similar matters as a way of adjusting to the demands of the 'hot seat' (Daresh 2000). The concept of reflection is no longer contested. The unresolved phenomenon is 'how', 'when' and 'to what extent' in the present day work contexts, in view of the issues of time management for those in leadership positions, and the tensions around balancing action and reflection:

... the headlong pressure on educational leaders 'to act, to do, to be the leader', which militates against a reflective attitude - a stance which is needed for the growth of worthwhile values and of character (Greenfield \& Ribbins 1993:258-9).

This draws attention to another dominant feature of leadership in Islam, being voiced strongly in the recent literature on leadership - the emphasis on moral and ethical values for leaders and teachers (Shah 2006). The Quran lays down an explicit charter of values and morality aiming at self-discipline and character building. The Prophet is an expression of these moral and ethical values, as the Quran vouches, 'And most surely you conform (yourself) to sublime morality' $(68: 4)$. The growing recognition of 'meditation 
on values' (Greenfield and Ribbins 1993:262), and perception of 'Leadership a Moral art' (Hodgkinson 1991; 1996; also Greenfield and Ribbins 1993; Sergiovanni 1992) in the recent leadership literature recognizes this dimension by arguing that leaders have to take value-positions:

Notions of caring, justice and ethics are the foundations ... The actions of the leader cannot be separated from the value positions held, for understandings of 'right', 'wrong', or even '(not) appropriate', depend upon recognition of individual world views and beliefs. (Goddard 2003:17)

Many research studies have highlighted the significance of leadership values in institutional contexts as contributive to 'success' (Begley and Johansson 2003; Bennet and Anderson 2003; Day 2000; Harris and Chapman 2002; Harris et al 2003; Hopkins 2001). A recent paper by Kathryn Riley discusses the 'moral and ethical imperatives that drive school leaders' (Riley et al 2004:2), arguing for leadership grounded in personal values drawing from ethical and moral roots. For Islamic leadership, the ultimate source of these values is faith and religious philosophy, but the aim in both cases is an emphasis on basic human values and a realization to develop a 'distinction between right and wrong':

"If moral leadership is to be exercised and pedagogy re-engineered with any degree of success, then future leaders will need a firm set of values. No doubt many will have their own list, but integrity, social justice, humanity, respect, loyalty and a sharp distinction between right and wrong, will all need to be included'. (Bennet 2000:3)

This reinforces the Islamic perspective of emphasis on values. Muslims, as a 'community of believers ${ }^{21}$, have always been as diverse and dense regarding culture, colour, language, ethnicity, dress, and others, as a present day multi-cultural school in Britain. A point worth considering is does the need for values increase with increased diversity! Is it 
the multicultural nature of Muslim Ummah that underpins the emphasis on values and inclusion, and to what extent can that approach be inclusive of non-Muslim perspectives?

Islam proclaims equality and fraternity, and strongly favours consensus as the desirable source of decision-making (Ahmed 1992; Nasr 1985). The emphasis on equality and justice in Islam aims at inclusion and embracing diversity (the Quran 49:13). This requires an understanding and recognition of the values of all the diverse groups, addressing the issues around 'whose values' or 'what values'. If values with morals and ethics are 'the very stuff of leadership' (Hodgkinson 1991:11), the issue of 'whose values' gains central significance. Riley et al (2004:9) attend to the issue by discussing the extent to which the leader's values and beliefs, the school's values and beliefs and the community's values and beliefs are harmonized for effectiveness.

The harmonization of multiple value-perspectives presupposes interaction between the leaders and the led - the led having more understanding of their situation than the leader (Freire 1972; 1973). This dialogical leadership is another concept embedded in Islamic philosophy, where the mosque offered the space for dialogue, and where the Prophet engaged in dialogue with individuals and learners five times a day. Fatima Mernissi (1991a) highlights the prophet's willingness and patience to listen to opinions and arguments, and to reflect on these before making any responses. The concepts of Ijtihad (Ahmed 1992) and Shura (Mernissi 1991a) are some other expressions of dialogical leadership. Dialogue, as a two-way activity, provides knowledge and understanding to take informed value positions and make decisions. This can be valuable for the educational leaders, particularly in multi-ethnic contexts, to immerse themselves in their community of learners to understand how certain actions are perceived and understood by diverse sub-groups, because for those in marginalized communities, school leaders are predominantly outsiders. Reaching across these divides, with a focus on internal and external linkages helps build bridges:

'The more we learn about others, the more collaborative, responsive, and linked to self-interests will be the work we can do with our partners' (Rubin 2002:xi) 
The notions of collaboration and sharing change epistemic orientation in context - in the external-to-school context the focus is on net-working, links, relationships; in the internal-to-school context it has come to be perceived as distributed leadership (Fullan 2001; Harris 2002; Harris and Lambert, 2003; Hopkins 2001; Telford 1996). Theoretically, both evolve from the premise of democratic practices underpinned by communication. Engaging many people in leadership activity is at the core of distributed leadership in action. The notion 'extends the boundaries of leadership significantly as it is premised upon high levels of 'teacher involvement' and encompasses a wide variety of 'expertise, skill and input' (Harris and Lambert 2003:16). Hopkins (2001) claims that the form of leadership most often associated with improved learning outcomes is one that is distributed or shared. The focus is the learner, as in Islam, and the aim is 'achievement/effectiveness' ('holistic development'!), which certainly requires a pooling together of leadership from all levels, and thus places increased emphasis on teachers' leadership role and leaders' teaching role. This does involves a 'transformational' dimension, providing both intellectual stimulation and individual support to all those being led (Burns 1978). Burns concept of transformational leadership is predicated on a positively educative engagement between leaders and followers. Leithwood et al (1996) perceive it as a vision-driven planning for the future, focusing on continuous improvement, which again agrees to Islamic notion of developing Insan-e-kamil - a complete person (Siddiqui 1998:1), and fits well within the frame of haqook-al-abaad and haqook-Allah. These developing concepts are moving towards a blurring of boundaries between leader/teacher, led/leaders, and internal-to-school/external-to-school, a position taken by Islamic philosophy of education, as discussed above:

Does this point to the need to reconstruct the notions of leadership, drawing from diverse perspectives?

Does this indicate the significance of perspectives formulated within multi-ethnic communities (i.e. Muslin Ummah), and to 'look analytically at those different conditions of production of theory and assess how far ... [these] insights are transferable to our situation' (Robbin 2004:429)? 


\section{Conclusion: overlaps in conceptual frameworks of educational leadership}

There is no denying the tensions across conflicting ideological positions and concepts, but this does not negate working towards increased understanding. An understanding of the factors influencing Islamic notions of leadership, and of other perspectives, can be useful for inclusiveness, particularly in the wake of increasing assumptions and misconceptions raging across the historic divide of Muslim/non-Muslim hindering understanding and causing concerns in multi-ethnic societies like Britain (Convay 1997). Research confirms that in the educational institutions, assumptions about Muslims and their socio-cultural practices tend to influence attitudes and practices towards the Muslim staff and students, affecting their achievement and performance (Abbas 2002; Connolly \& Troyna 1998; Haw 1998; Mac an Ghaill 1994; Osler 1997; 2003; Parker-Jenkins 1995; Rakhit 1998). The performance and progression issues of the Muslim students and the staff in Britain are increasingly being perceived as leadership issues. The assimilation approaches practised in schools as a reaction and response to increased immigration in the post-second-worldwar scenario complicated the leadership-management of 'multi-ethnic' schools by camouflaging the real issues.

The emerging leadership concepts reflect genuine efforts to restructure leadership in a realistic context, based on an acknowledgement and celebration of diversity, corresponding to Islamic philosophy and may be to many others. An Islamic leadership perspective is not a matter of notional constructions of 'knowledge-givers' through religious texts and discourses. It is a quintessence of all those principles and values associated with the 'righteous path', and which have high value for the Muslims. These concepts have a bearing on the attitudes, code of conduct, behaviour and demeanour of educational leaders in the Muslim societies. A model educational leader, from the Muslims' perspective has to be value-conscious irrespective of the fact to what extent do they follow that path themselves (Jacobson 1998). Islam celebrates diversity (The Quran 49:13), and declares that faith can not be imposed by force. Coming from this philosophical position, the Muslim students and community would understand differences of culture and faith, but they would expect the leaders to live up to a value model to command that respect 
and relationship which, in Islam, forms the basis of teaching and leading. The 'sensemaking agenda' suggested by Tim Simkins draws attention to the emerging contexts and associated needs by highlighting the need for 'making sense' of:

- the ways in which leadership itself is conceived;

- the role and purposes of the organization within a dynamic and conflictual policy environment;

- the ways in which leadership roles are changing and should change;

- the ways in which power and authority are and should be constituted and distributed in educational organizations;

- 'other worlds' across inter-professional and organizational boundaries; and

- using leadership development to understand sense-making itself.

Leadership perspectives are not fixed entities. These evolve and develop, although the nature and scope of change may vary from context to context. Even within Muslim societies there are considerable variations in practice over time and across regional cultures (Siddique 1998), in spite of a shared philosophical base. Across philosophical and other divides, differences might be more pronounced in practice, but a base of shared human values can guide to resolve tensions, not by eliminating differences, but by respecting and integrating conflicting philosophies and concepts. A pre-requisite is communication and, according to Hofstede, ccommunication across cultures 'stimulates reflection and reorientation' (2001: 390), which may mean a reorientation of leadership theory in the case of educational leadership, moving towards construction of a leadership model to the satisfaction of component groups in multicultural institutions. We certainly need complex theoretical constructs to reconfigure and re-conceptualize leadership in complex contexts. This paper argues for engaging with, and drawing from, diverse sources to enrich theory and practice and to develop leadership model to meet the challenges of changing population structures in schools, and suggests engagement with diverse leadership perspectives to work towards that goal. 


\section{Agenda for Research into Islamic Educational Leadership in Britain}

In spite of a large Muslim population in Britain, research into Islamic Educational Leadership remains a neglected field, as in many other countries. In the emerging multicultural multi-faith societies, with the surfacing of a global wave of religious resurgence, the need to enhance knowledge and understanding of diverse communities gains extreme significance, particularly to maintain social stability and harmony that contribute to educational engagement. This places tremendous responsibility on educational leaders who are expected to provide not just the future work force but also the future citizens with respect for plurality and diversity of values perspectives. As I argue elsewhere (Shah 2006), lack of understanding and lack of respect for diversity can create a context of conflict and resentment that may ultimately contribute to occurrences like 9/11 and 7/7. Educational leaders and researchers have responsibility to develop a knowledge base that can improve mutual understanding and respect. In the case of Muslim community, a basic research agenda may focus on building that knowledge base by exploring:

- Quranic philosophy of education - towards making education a positive experience

- Teacher/leader and knowledge status in Islam and its implications for teaching/learning

- Conceptualisations of educational leadership in Muslim and non-Muslim communities/ societies

- Muslim learners' expectations of educational Leadership in Britain

- Experiencing Muslimness in educational institutions in Britain

- Muslim learners' perceptions of leadership, and leadership perceptions of Muslim learners: the interplay

- Faith, citizenship and education

The world has moved on from 'one-nation country' scenario, and in today's multiply diverse global village the issue is to learn how to live together. The only long term effective option appears to be to enhance knowledge and understanding, and this brings the focus back to further research. No doubt there are, and will be, issues of how and who 
and what in research, challenging ontologies, epistemologies and methodologies. But even if we don't agree on any answers, at least the questions raised will make us all think.

\section{Acknowledgements:}

Thank you to colleagues for their very useful comments, and support, in developing this paper.

\section{Bibliography:}

Abbas, T. (2002) Teacher perceptions of South Asians in Birmingham schools and colleges, Oxford Review of Education,_28(4) 447-471.

Abdullah, A. S. (1982) Educational Theory: A Quranic Outlook. Umm-Al-Qura University, Makkah. Saudi Arabia.

Ahmed, A. S. (1992) Post-Modernism and Islam: Predicament and Promise. London, Routledge.

Ahmed, A. S. and Donnan, H. (eds.) 1994, Islam, Globalization and Postmodernity. London: Routledge.

Ahmed, L. (1992) Women and Gender in Islam: Historical Roots of a Modern Debate. Yale University Press.

Al-Ahsan, A. (1992) Ummah or Nation: Identity Crisis in Contemporary Muslim society. The Islamic Foundation: Liecester.

Al-'Arîn, Muhammad (1993) Tahâfut al-Tahâfut li-Ibn Rushd, Dâr al-Fikhr al-Lunbânî; Bairût.

Al-Attas, M (1979) Aims and Objections of Islamic Education. Hodder and Stoughton: King Abdul Aziz University; Jeddah: Saudi Arabia.

Al-Bukhari, S. M.; Sahih l-Bukhari Vol. 1. Translated by Dr. Muhammad Muhsin Khan et al.Lahore, Dar-us-Salam Publications.

Al-Ghazali, S. (translated in 1963) Tahafut al-falasifah [incoherence of the philosophers / translated into English by Sabih Ahmad Kamali. Lahore: Pakistan Philosophical Congress.

Al-Hibri, A. (ed.) 1982, Women and Islam. Oxford: Pergamon Press. Published as a special issue of Women's Studies International Forum, (5) 2. 
Ali, B. (2005) The Aga Khan University-Examination Board: Does Pakistan Need One? Accessed on Jan. 31, 2005: http://www.chowk.com/show_article.cgi?aid=00004107\&channel=university\% 20 ave \&start $=0$ \&end $=9$ \& chapter $=1$ \& page $=1$

Ali, S. A. (1964) The spirit of Islam: a history of the evolution and ideals of Islam with a life of the Prophet. London: Chatto \& Windus.

Al-Kindî (1950) On the True Agent, in Al-Kindî, fî al-Falsafa al-Ûlâ, in Abû Rîda (ed.) Risâ'il al-Kindî al-Falsafiyya, (Cairo 1950), vol. 1, pp. 182-4.

Anwar, M. (1998) Between cultures: continuity and change in the lives of young Asians. London: Routledge.

Ashraf, S. A. (1995) 'Basic Principals in the Formulation of Curriculum for Tertiary Education with Specific Reference to Humanities', in Muslim Education Quarterly, (13)1, pp 5-11.

Bauman, Z. (1996) Culture, Modernity and Revolution: essays in honour of Zygmunt Bauman; edited by R. Kilminster and I. Varcoe. London: Routledge.

Bauman, Z. (1997) Postmodernity and its Discontents. Cambridge: Polity.

Begley, P. (2003) 'Western-Centred Perspectives on Values and Leadership' in M. Warner, M. and Joynt, P. (eds.) Managing across cultures: issues and perspectives, London: Thomson Learning: pp 45-60.

Begley, P. and Johansson, O. (eds.) 2003, The Ethical Dimensions of School Leadership. Dordrecht ; London: Kluwer Academic.

Bennett, D. (2000) The School of the Future, National College for School Leadership, Leadership Evidence Base (Nottingham, NCSL).

Bennett, N. and Anderson, L. (eds.) 2003, Rethinking educational leadership: challenging the conventions. London: Sage.

Bloom, B., Krathwohl, D. R. and Masia, B. (1964) Taxonomy of educational objectives : the classification of educational goals. Handbook 2, Affective domain. London: Longmans.

Boleman, L. G. and Deal, T. E. (1997) Reframing Organisations: artistry, choice, and leadership; $2^{\text {nd }}$ edition. San Francisco: Jossey-Bass Publishers.

Bourdieu, Pierre and Passeron, Jean-Claude (1977) Reproduction in education, society and culture. London: Sage Publications.

Brah, A., Hickman, M. J. and Mac an Ghaill, M.(eds.) 1999, Global futures: migration, environment and globalization. Basingstoke: Macmillan.

Brah, Avtar (1996) Cartographies of diaspora: contesting identities; London: Routledge.

Braun, W. and Warner, M. (2003) 'The 'culture-free' versus 'culture-specific' management debate' in M. Warner and P. Joynt (eds.), op cit; pp 13-25.

Burns, J. M. (1978) Leadership. New York ; London : Harper \& Row.

Cheng, Y. C. (2002) 'Leadership and Strategy', in T. Bush and L. Bell (eds.) The Principles and Practice of Educational Management. London: Paul Chapman. 
Child, J. (2003) 'Theorising about organisation cross-nationally: part 2...' in Warner and Joynt (eds.) op cit; 40-56.

Choudhury, M. A. (1993) 'A Critical Examination of the Concept of Islamisation of Knowledge in Contemporary Times'. Muslim Education Quarterly, 10(4) 3-34.

Christie, C. J. (1991) 'The Rope of God: Muslim Minorities in the West and Britain', in New Community 17(3), pp 457- 466.

Connolly, P. \& Troyna, B.(eds.) Researching Racism in Education: politics, theory and practice. Buckingham: Open University Press.

Convay, G. (1997) Islamophobia, a challenge for us all: report of the Runnymede Trust Commission on British Muslims and Islamophobia. London: Runnymede Trust.

Daresh, J. \& Male, T. (2000) 'Crossing the Border into Leadership: Experiences of Newly Appointed British Headteachers and American Principals'. Educational Leadership and Management, 28(1) 89-101.

Dabashi, H. (1993) Theology of discontent: the ideological foundations of the Islamic Revolution in Iran. New York: New York University Press.

Davies, B. J. and Davies, B. (2004) 'Strategic Leadership'. School Leadership and Management, 24(1), 29-38.

Day, C. (2000) Leading Schools in Times of Change. Buckingham: Open University Press.

Dimmock, C. (2002) 'Taking account of complex global and cultural contexts', in A. Walker and C. Dimmock (eds.) School leadership and administration: adopting a cultural perspective, London, Routledge Falmer, pp 33-44.

Dimmock, C. (2000) Designing the learning-centred school: a cross-cultural perspective, London: Falmer Press.

Dimmock, C. and Walker, A. (2002) 'School Leadership in Context - societal and organizational cultures', in T. Bush and L. Bell, The principals and practice of educational management, London, Paul Chapman Publishing; 70-85.

Foucault, M. (1977) Discipline and punish: the birth of the prison / translated from the French by Alan Sheridan. London: Allen Lane

Foucault, M. (1980) Power/Knowledge: Selected Interviews and Other Writings, (19721977). Brighton: Harvester Press.

Foucault, M. (1988) Politics, Philosophy and Culture; Interviews and Other Writings 1977-1984/ A Sheridon and others. New York : Routledge.

Freire, P. (1973) Education for critical consciousness. London: Sheed and Ward.

Freire, P. (1972) Pedagogy of the Oppressed. Harmondsworth: Penguin.

Fullan, M. (2001). Leading in a culture of change. San Francisco: Jossey-Bass/Wiley.

Fullan, M (1992) What Is Worth Fighting For In Headship? Strategies for Taking Charge of the Headship. Buckingham: OUP. 
Geaves, R. (1996) Sectarian influences within Islam in Britain: with reference to the concepts of 'Ummah' and 'Community'. Leeds: University of Leeds, Department of Theology and Religious Studies.

Giddens, A. (1990) The Consequences of Modernity. Cambridge: Polity Press.

Giddens, A. (1993) Sociology, 2nd rev. ed. Cambridge: Polity Press.

Goddard, J. T. (2003) 'Leadership in the (Post) Modern Era', in N. Bennett and L. Anderson (eds.) op. cit; pp11-26.

Greenfield, T. and Ribbins, P. (1993) Educational Administration: Towards A Humane Science. Routledge: London, New York.

Greenleaf, R. K. (1996) On becoming a servant leader. San Francisco:Jossey-Bass. Habermas, J. (1976) Legitimation Crisis. London: Heinemann.

Haddad, Y. Y. (ed.) 2002, Muslims in the West: from sojourners to citizens. Oxford: Oxford University Press.

Hall, S. (1993) 'Cultural identity and diaspora', in Williams p. and Chrisman, L. (eds.) Colonial Discourse and Post-Colinial Theory: A Reader, London: Harvester Wheatsheaf; 392-403.

Handy, C. (1995) Gods of management. London: Arrow.

Harris, A. and Lambert, L. (2003) Building Leadership Capacity for School Improvement. Maidenhead: Open University Press.

Harris, A., Day, C., Hopkins, D., Hadfield, M., Hargreaves, A., and Chapman, C. (2003) Effective Leadership for School Improvement. London: Routledge Falmer.

Harris, A (2002) Effective leadership in schools facing challenging contexts. School Leadership And Management, 22(1) 15-26.

Harris, A. and Chapman, C. (2002) Effective Leadership of Schools Facing Challenging Circumstances. NCSL Research Project.

Haw, K. (1998) Educating Muslim girls: shifting discourses (with contributions from Saeeda Shah and Maria Hanifa). Buckingham: Open University Press.

Hodgkinson, C. (1991) Educational Leadership: The Moral Art. State University of New York Press.

Hodgkinson, C. (1996) Administrative Philosophy. Values and motivations in administrative life. London: Pergamon.

Hofstede, G. (2001) Culture's Consequences, $2^{\text {nd }}$ edition. Thousand Oaks, Calif.; London: Sage Publications.

Hopkins, D. (2001) School Improvement for Real. London: Routledge/Falmer.

Hughes, M. (1990) 'Institutional Leadership. Issues and Challenges', in R. Saran and V. Trafford (eds.) Research in Education Management and Policy. London:

Falmer; pp 24-35.

Huq, M. S (1954) Compulsory education in Pakistan. Paris: UNESCO

Hussain, I. (2005) How Pakistan's political parties continue to block progress. Khaleej Times Online; Jan. 13, 2005.

Hussain, S. and Ashraf, A. (1979) Crisis in Muslim Education. Hodder and Stoughton: King Abdul Aziz University. Jeddah: Saudi Arabia. 
Iqbal, M. (1981) Education in Pakistan. Aziz Publishers; Lahore: Pakistan.

Iqbal, M. Z. (1996) Teachers Training: The Islamic Perspective. Institute of Policy Studies and International Institute of Islamic Thought. Islamabad: Pakistan. Jacobson, J. (1998) Islam in transition: religion and identity among British Pakistani youth. London: Routledge.

Karim, F. (1938) Al Hadith: Volume One. The Book House. Lahore: Pakistan.

Kolb, D. A. (1984) Experiential Learning, Englewood Cliffs, N.J., Prentice-Hall.

Leithwood, K., Tomlinson D., and Gene, M (1996) 'Transformational School Leadership' in K. Leithwood et al (eds.) International Handbook of Educational Leadership and Administration. Dordrecht; London: Kluwer Academic.

Mac an Ghaill, M. (1994) The Making of Men: masculinities, sexualities and schooling. Buckingham: Open University Press.

Marsh, Colin (1994) 'An Analysis of Selected School Improvement Practices', in N. Bennett, R. Glatter and R. Levacie (1994) Improving Educational Management Through Research and Consultancy. London: Paul Chapman and OUP.

Maududi, Sayyid Abula'la (1980) The Islamic law and constitution; translated by Khurshid Ahmad. Lahore: Islamic Publications. Pakistan.

Mernissi, F. (1991) Women and Islam: A Historical Enquiry. Basil Blackwell. Oxford.

Mernissi, F. (1991a) The Veil and the Male Elite. Perseus Book, Camberidge, Massachusetts.

Miller, T. W. G. (1968) Education in South East Asia. Ian Novak: Sydney.

Modood, T. (1997) Ethnic Minorities in Britian: diversity and disadvantage. London: Policy Studies Institute.

Modood, T. (1990) 'British Asian Muslims and the Rushdie Affair'. Political Quarterly 61(2) 143-160.

Modood, T. (2005) 'Ethnicity and Intergenerational Identities and Adaptations in Britain: The Socio-Political Context' in Rutter, M. \& Tienda, M. (eds.) Ethnicity and causal mechanisms. New York \& Cambridge: Cambridge University Press; pp 281-300.

Mullins, L. J. (1995) Management and Organisational Behaviour. London: Pitman.

Murphy, J. (1971) Church, state and schools in Britain, 1800-1970. London: Routledge and Kegan Paul.

Nasr, S. H. (1985) Ideals and Realities of Islam. London: George Allen and Unwin.

National Education Policy (1998-2010) Ministry of Education, Government of Pakistan. Islamabad: Pakistan. Also on: http://www.pakistan.gov.pk/educationministry/highlights/highlight-three1.jsp

National Statistics (2001) Office for National Statistics http://www.statistics.gov.uk accessed on 7 May 2003. 
Nayyar, A. H. and Salim, A. (eds.) The Subtle Subversion: The State of Curricula and Textbooks in Pakistan. Sustainable Development Policy Institute; Islamabad: Pakistan.

Nielsen, J S. (1992) Muslims in Western Europe. Edinburgh UP.

Nielsen, G. (1987) 'Muslims in Britain: searching for an identity'. New Community, 13(3) 384-394.

Osler, A. (1997) The Education and Careers of Black Teachers: changing identities, changing lives. Buckingham: Open University Press.

Osler, A. (2003) 'Muslim Women Teachers: life histories, identities and citizenship', in T. Benn and H. Jawad (Eds.) Muslim Women in the United Kingdom and Beyond: Experiences and Images Women and Gender: The Middle East and the Islamic World, 2. Netherlands: Brill.

Parker-Jenkins, M. (1995) Children of Islam: a teacher's guide to meeting the needs of Muslim pupils. Stoke-on-Trent: Trentham.

Polanyi, M. (1967) The Tacit Dimension. London: Routledge: Kegan Paul.

Pugh, D. S. and Hickson, D. J. (2003) 'On Organisational Convergence', in M. Warner and P. Joynt (eds.), op cited.

Rakhit, A. (1998) 'Silenced voices: life history as an approach to the study of South Asian women teachers', in: P. Connolly \& B. Troyna (eds) Researching Racism in Education: politics, theory and practice. Buckingham: Open University Press.

Reeves, F. (1995) The Modernity of Further Education: The Direction of Change in Further Education Colleges. Bilston: Bilston College in Association with Education NOW.

Ribbins, P. (2003) 'Preparing For Leadership In Education: in search of wisdom' in N. Bennett and L. Anderson (eds.) op cit.

Riley, K. A. in partnership with Hesketh, T., Rafferty, S., Young, J., Taylor-Moore, P., Beecham, Y., Morris, S., and West-Burnham, J. (2004) Leading Challenging Urban Schools: demands, dilemmas \& dreams. Paper to the American Educational Research Association, April 2004,-San Diego.

Robbin, D. (2004) 'The transcultural transferability of Bourdieu's sociology of education'. British Journal of Sociology of Education; 25(4), 415-431.

Rubin, H. (2002) Collaborative leadership: developing effective partnerships in communities and schools. Thousand Oaks, Calif.: Corwin Press.

Schon, D. A. (1987) Education and the Reflective Practitioner: Towards a new design for teaching and learning in the professions, San Francisco: Jossey-Base.

Schon, D. A. (1983) The Reflective Practitioner: How Professionals Think In Action. New York: Basic Books.

Sergiovanni, T. J. (1992) Moral Leadership. San Francisco: Jossey-Base.

Sergiovanni, T. J. (1984) Leadership and Excellence in Schooling'. Educational Leadership, 41(5), 4-13. 
Shah, S. (2006) 'Leading Multiethnic Schools: a new understanding of Muslim Youth Identity'. Journal of Educational Management, Administration and Leadership; accepted for the Special Edition - Leadership and Diversity: Vol 34(2) pp 215-237.

Shah, S. (2004) 'The Researcher/Interviewer in Intercultural Context: a social intruder'. British Educational Research Journal, 30(4) 549-575.

Shah, S. (1999) 'Islam and Knowledge ...'. Journal of the Faculty of Islamic Studies and Arabic. University of Peshawar, Pakistan; 4(2), 52-68.

Shah, S. (1999a) Education Management: braving boundaries. National Book Foundation, Govt. of Pakistan, Islamabad.

Shah, S. (1998) Educational Management ... PhD thesis at the University of Nottingham.

Siddiqui, A. (1998) Islam and Education. Paper presented at a panel discussion at Shaykh Zayed Islamic Centre, University of Peshawar (Pakistan), on 7 March 1998.

Simkins, T. (2005) 'Leadership in Education: 'what works' or 'what makes sense'?' in Educational Management, Administration and Leadership; 33(1), 9-26.

Sternberg, R. (2002) Wisdom, Schooling and Society. Keynote presentation to the International Thinking Skills Conference, Hrrogate.

Tibawi, A. L. (1972) Islamic Education. Luzac and Company Ltd.: London.

Talbani, A. (1996) 'Pedagogy, Power, and Discourse: Transformation of Islamic Education'. Comparative Education Review; 40(I) 66-82.

Tajfel, H. (1978) 'Interindividual behaviour and intergroup behaviour' in H. tajfel (ed.) Differentiation between social groups: studies in the social psychology of intergroup relations. London: Academic Press.

Telford, H (1996) Transforming Schools through Collaborative Leadership, Falmer.

The Guardian, September 21, 2001.

The Guardian, June 17, 2002.

Tibawi, A. L. (1972: Islamic Education. Luzac and Company Ltd.: London.

Tung, R. L. (2003) 'Managing in Asia: cross-cultural dimensions' --- in Warner and Joynt (eds.) op cit; pp 137-142.

Vincent, C. (ed) 2003, Social justice, education, and identity. London: Routledge Falmer.

Walker, A. (2002) 'Hong Kong principals' dilemmas:basic management and consequenc' in A. Walker and C. Dimmock (eds.) op cit, pp 205-221.

Walker, A. and Dimmock, C. (2002) 'Cross-cultural comparative insights into educational administration and leadership', in A. Walker and C. Dimmock (eds.) op cit, pp 13-32.

Watt, M. (1961) Muhammad, Prophet and Statesman. London: Oxford University Press.

\footnotetext{
${ }^{1}$ Giddens (1993) defines ethnocentrism as 'judging other cultures by comparison to one's own', arguing that 'a culture has to be studied in terms of its own meanings and values ... Since human cultures vary so widely, it is not surprising
} 
that people coming from one culture frequently find it difficult to sympathise with ideas or behaviour of those from a different culture' (39).

${ }^{2}$ Ummah is the overarching concept used for wider Muslim community, operative beyond geo-political bounds. The root word of Ummah is umm which means 'mother' in Arabic (Ahmed 1992). In the first chapter of 'Ummah or Nation', Dr. Al-Ahsan (1992) discusses the Quranic concept of Ummah, referring to the sixty-four occurrences of the term in the Quran. Commonly, this term is used among Muslims to convey the fact that all Muslims the world over constitute one ummah or community (see also Geaves 1996 (chapters II and III); Iqbal 1996).

${ }^{3}$ Some discussions in Al-Ghazâlî, Al-Kindî and Ibn Rushd can help to understand these debates.

${ }^{4}$ This concept of education for all forms the basis of Islamic philosophy of education, while in many early societies access to education has been limited. For example in early church schools, education was limited to clergymen and landlords (Murphy, 1971), while in the pre-Islamic India education was the privilege of the Brahmins, and only restricted learnings (three Rs) were permitted to Kshatriyas and Vaisyas, completely excluding the Sudras (Haq 1954; Miller 1968).

${ }^{5}$ The two point agenda of 'education for all' and 'lifelong learning' which is increasingly gaining credibility in the developed world.

${ }^{6}$ One of the five pillars of Islam, and a highly contested concept, which essentially stands for struggle in Islam. The two major terms associated with it are: 'Jihad bil-Ilm', which means effort through knowledge; and 'Jihad bil-Saif' which signifies the 'defense of Islam', where 'saif' literally means sword. Jihad in all its forms symbolises a struggle for the 'right', valuable than one's own life, and carries promises of highest reward. See also Christie 1991; Nielsen 1992).

${ }^{7}$ There are examples of the Mohammed's (the prophet in Islam) insistence for the Muslims to pursue knowledge wherever they find it 'even to the borders of China' (Ashraf 1995).

${ }^{8}$ The Prophet (peace be upon him) said: 'Whomsoever Allah intends to do good, He gives right understanding of religion, and knowledge is maintained only through teaching.' (Hadith Bukhari in A Manual of Hadith by Maulana Muhammad Ali).

9 'Sijda' (bowing the head) in the Islamic context is the ultimate mark of respect and obedience, and except this one reference in the Quran, due only to God.

${ }^{10}$ The interrogative expression is often used in the Quran for emphasis.

${ }^{11}$ Some prophets named in the Quran as having been given knowledge are Noah, David, Solomon, Moses (28:24), Joseph (12:22), and Jacob (12:68).

${ }^{12}$ For details see Hussain and Ashraf 1997: 'The Teacher and the Taught', and Iqbal 1996:61-111.

${ }^{13}$ Later, the situation underwent changes as Islam spread into further areas, and interacted with different religions, and socio-economic backgrounds. Al-Azhar was the first formal seat of learning established in Egypt in the fourth century, and was followed by Al-Nizamiyyah in Baghdad, where state-paid teachers were appointed (Tibawi 1972:30).

${ }^{14}$ Ulema have traditionally commanded high respect and status in Muslim societies due to their knowledge, but there has been an increasing dissatisfaction with their knowledge claims in the present times.

${ }^{15}$ Religious knowledge, broadly speaking, includes knowledge of the sacred texts, and knowledge about the pillars of the religion, the articles of faith, and the Shari'ah.

${ }^{16}$ Believing and obeying the Quranic teachings is a part of faith for Muslims.

${ }^{17}$ Schools run by 'Nahlatul Ulama' (Educational Management News, Issue 22, Jan 2004, p 13.

${ }^{18}$ Cheng (2002) lists five dimensions of leadership - human, structural, political, cultural and educational - developed from Boleman and Deal's (1997) four leadership functions, and Sergiovanni's (1984) model of five leadership forces - technical, human, educational, symbolic, and cultural leadership, which point to the scope and depth of leadership concepts.

${ }^{19}$ Davies and Davies define wisdom as 'the capacity to take the right action at the right time' (2004:35) - a simple definition which can absorb multiple interpretations.

${ }^{20}$ In Islamic philosophy, God is 'the Knowing', 'the Wise' $(4: 11 ; 4: 24 ; 4: 92 ; 4: 111 ; 4: 170 ; 6: 83 ; 6: 139 ; 8: 71 ; 9: 15$; $12: 100 ; 15: 25 ; 22: 52 ; 33: 1$ and many others). Human leadership is justified in the Quran on the basis of human beings partaking these Godly attributes of 'the Knowing' and 'the Wise'.

${ }^{21}$ A highly diverse community, extending beyond the variables like race, 'ethnicity', colour, language, dress, and others. 